personale gir uttrykk for at dette er innleggelser som er relevante for akuttavdelingen. Vi kan finne nærmere ut om dette ved blant annet å se på pasientenes symptom- og funksjonsnivå (GAF-skår). Jeg mener at det ikke er ressursmessig fornuftig å ha heldøgnsbemannede akutteam ved distriktspsykiatrisk senter. Vår beredskap i dag tar hånd om de aller fleste «livskrisehendelser». De aller fleste pasientene som legges inn ved psykiatrisk akuttavdeling fra vårt opptaksområde har behov for denne avdelingens rammer.

Ole-Bjørn Kolbjørnsrud

Notodden/Seljord DPS

\section{Protonpumpehemmere og reseptfrihet}

Helge L. Waldum uroer seg i Tidsskriftet nr. 21/2009 for protonpumpehemmeres langtidsbivirkninger, og hevder de ikke bør selges reseptfritt (1).

Som kommentar til Waldums uro for bivirkninger kan nevnes at det kliniske utviklingsprogrammet av substansen pantoprazol omfatter 250 studier på 80500 pasienter. Den gunstige bivirkningsprofilen kan interesserte lese om i detalj. Bivirkningsdata rapporteres offentlig under den korte produktoversikten på Statens legemiddelverks hjemmeside og ekspertrapporten (EPAR) på hjemmesiden til European Medicines Agency (2). Waldum konstaterer at tidsbegrensede pasientstudier ikke kan avsløre langtidsbivirkninger, men det finnes naturligvis et regelverk rundt langtidsoppfølging av legemidler. Etter lanseringen av pantoprazol er 733000 behandlinger gjennomgått i de såkalte Post-Authorisation Safety Studies (2). Hensikten med disse er å oppdage nettopp uvanlige bivirkninger. Dessuten følger Nycomed myndighetenes krav om en omfattende oppfølging med legemiddelovervåking. Siden lanseringen av pantoprazol i 1994 har 665 millioner pasienter på verdensbasis fått pantoprazolbehandling. European Medicines Agency har ikke identifisert noen nye sikkerhetsrisikoer siden det.

Pantoprazol har vært reseptfritt i Sverige siden februar 2000. Det har ikke vært tegn til at reseptfriheten har bidratt til feil bruk eller påvirkning av legemidlets sikkerhetsprofil (2). Nycomed har da også lagt vekt på at pasientene skal informeres i pakningsvedlegget om at man må kontakte lege om symptomene ikke forbedres i løpet av to uker, samt at de ikke skal ta tablettene i mer enn fire uker.

Det er derfor etter vårt skjønn ingen grunn til å tvile på at det er trygt å tilby norske pasienter muligheten til å bruke pantoprazol reseptfritt for reflukssymptomer som reduserer livskvaliteten.
Mikael Gellerfors

Nycomed Pharma

\section{Litteratur}

1. Waldum HL. Protonpumpehemmere bør ikke selges reseptfritt. Tidsskr Nor Legeforen 2009: 129: 2263

2. European Medicines Agency www.emea.europa eu/humandocs/PDFs/EPAR/Somac_Control/ H-1098-en6.pdf (15.12.2009).

\section{Risikoskår og TIA-pasienter}

I vår artikkel

i Tidsskriftet nr.

22/2009 presen-

terte vi ABCD-

skår som et red-

skap til å risikostratifisere TIApasienter, slik at lavrisikopasienter kan identifiseres og tilbys rask

poliklinisk utred-

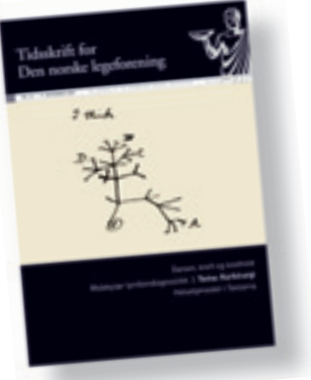

ning og behandling og de med høy risiko innlegges direkte i sykehus (1). I artikkelen er skår $\geq 5$ anført som beslutningsgrense mellom lav- og høyrisikopasienter. Dette kan innebære at enkelte med skår 4 ikke får rask nok vurdering, noe som best kan løses ved umiddelbar innleggelse i sykehus. Ved å benytte skår $\geq 4$ som beslutningsgrense vil man kunne unngå dette. Det finnes internasjonale retningslinjer som benytter $\geq 5$ som beslutningsgrense (2), men i England hvor ABCD-skåren er mest utprøvd, er grensen satt til $\geq 4$ (3). Risikoen for å få et manifest hjerneslag de første dagene etter et TIA-anfall er $<1 \%$ hos pasienter med lavere skår enn 4, og. for de fleste pasienter i denne kategorien vil derfor en rask poliklinisk utredning være et trygt og godt alternativ til akutt innleggelse $(3,4)$. Vi vil imidlertid understreke at risikoskårer bare er veiledende og må suppleres med klinisk skjønn, også ved lav risiko. Klinisk praksis er individbasert, også i denne sammenhengen.

\section{Hanne Ellekjær \\ Torbjørn Dahl \\ Trondheim}

\section{Litteratur}

1. Dahl T, Ellekjær H. Carotisstenose - utredning og behandling. Tidsskr Nor Legeforen 2009; 129: 2374-7.

2. Stroke Foundation. www.strokefoundation.com au/images/stories/healthprofessionals/clinical $\% 20$ guidelines $\% 20$ for $\% 20$ acute $\% 20$ stroke $\% 20$ management.pdf (15.12.2009).

3. The National Collaborating Centre for Chronic Conditions. www nice.org.uk/nicemedia/pdf/ CG68FullGuideline pdf (15.12.2009).

4. Johnston SC, Rothwell P, Nguyen-Huynh M et al. Validation and refinement of scores to predict very early stroke risk after transient ischaemic attack. Lancet 2007: 369: 283-92.

\section{RETTELSE}

Overdosestatistikk et komplisert regnskap

Thomas Clausen, Ingrid A. Havnes, Helge Waal Tidsskr Nor Legeforen 2009; 129: 2233-6

I ovennevnte artikkel i Tidsskriftet nr. 21/2009 s. 2234 var det feil i figurteksten til figur 1. Figuren og tabellen bygger på politistatistikken slik denne ble publisert 30.4. 2008 og på tidligere SIRUS-rapporter. Politistatistikken er senere korrigert slik det er beskrevet i artikkelen. Det presiseres derfor at det er de korrigerte tallene som skal brukes videre. Disse finnes i rapporten Rusmidler i Norge 2008 (www.sirus.no/internett/alkohol/publication/ 464.html) og RusStat (http://statistikk.sirus. no/sirus/

\section{RETTELSE}

Overføring av spesialistgodkjenning

Einar Skoglund, Brit Torill Gutbier

Tidsskr Nor Legeforen 2009; 129: 2520

I Tidsskriftet nr. 23/2009, på side 2520, skal mellomtittelen i midtspalten være:

Nordisk overenskomst

\section{Tilsvarsrett}

Tidsskriftet praktiserer tilsvarsret i henhold til Vancouver-gruppens regler (www.icmje.org/ publishing_5correspond.html]. Dersom vitenskapelige artikler kommenteres i spalten, får artik kelforfatterne mulighet til å svar i samme nummer. Slik automare tilsvarsrett gjeld. Slik automatisk tere av vit gjelder kun for forfatDen gjelder imapelige artikler. debatten imidlertid ikke dersom Brev til redtsetter i spalten eksempel publisen, dvs. hvis det for til det første tilsvaret. 